\title{
Green supply management in the public and private sector in Hungary
}

\author{
Gyöngyi Vörösmarty, Tünde Tátrai \\ Corvinus University of Budapest \\ Department of Logistics and Supply Chain Management
}

\author{
Please cite this paper: \\ Vörösmarty, G., \& Tátrai, T. (2019). Green supply management in the public and \\ private sector in Hungary. International Journal of Procurement Management, 12(1), 41- \\ 55.
}

\begin{abstract}
This paper compares the green purchasing practices of the private sector with those of public procurement with the aim of identifying the causes of differences. Private sector purchasing in Western economies is often seen as a benchmark for public procurement in terms of efficiency, management processes and the management of spending. We present the results of a literature review and a survey about this topic that was carried out in Hungary. The number of publications that compare the two fields is low, even in Western countries; however, the Hungarian data and evaluation show similarities with earlier international findings. Results indicate that supplier management is more important for private organisations, while public entities focus on the procurement process and the administrative requirements of national regulations. Due to the lack of East European comparative studies, this paper follows the approach of the European and US literature in terms of concept development.
\end{abstract}

\section{Introduction}

Globally, environmental rising concern has directed organisations towards sustainable development and environmentally sensitive practices and this situation applies to both public and private purchasing. (Dubey et al, 2013) The results of a comparison of public procurement and private sector purchasing are of interest to both academics and practitioners, and the increase in attention is reflected in the number of mentions of this issue in various publications. Private sector purchasing is often seen as a benchmark for public procurement, as it is a challenge for public buyers to fulfil the requirements of regulations, ensure transparency, and ultimately deliver financially competitive solutions. Public procurement spending represents a major share of public sector outlay, so governments tend to combine procurement spending with other economic goals, such as supporting SMEs and protecting the environment. As the latter goal is supported by EU Public Procurement Directives (2014), it may be supposed that this has a positive effect on greening public procurement practices.

This paper addresses a research gap by investigating whether differences in the green procurement practices of the public sector and corporate sector exist. The paper highlights the fact that potential causes of any differences are related to the different influences of stakeholder groups and the different priorities of the two sectors. A set of propositions are used to help investigate differences in impact, in priorities and in green procurement practices. The purpose of the research is thus to test this framework.

The structure of the paper is as follows. First, a brief overview of literature describes findings about the reasons for the differences in the purchasing practices of the public and the private sector, with a focus on the background, the differences themselves, and green approaches. The 
second section presents the results of a survey. The related questionnaire was filled out in 2014 and 2015 by 89 purchasing and 46 public procurement professionals in Hungary. The paper presents an analysis of the reported differences in green activities, and develops potential explanations for these.

\section{Literature about differences in public procurement and purchasing}

The results of an extensive literature review confirm that, although the primary task of private firm purchasing and public sphere procurement is similar (obtaining goods and services for their organisations), the conditions for public procurement and purchasing are different. Explanations can be developed on a historical basis from the European and US literature, both streams having investigated the origins of purchasing behaviour. In the private sector, the growing size of firms and the increasing complexity of operations necessitated the evolution of a purchasing function. As highlighted by Leenders and Fearon (2007), by the end of the nineteenth century many publications were stressing the need for a supply function with appropriate roles and responsibilities, guided by more than price considerations, to promote efficient purchasing practices. The public procurement literature originated even earlier, and suggests that public procurement practices were developed hand in hand with public administration (Basheka, 2013). In the context of public administration, one important aim was to control the growing size of operations; however, improving efficiency was just one consideration - others included the desire to eliminate abuse and fraud.

Based on a literature survey, Telgen et al. (2007) describes the pressure public procurement professionals face in addition to that imposed on private sector procurement as follows:

- External demand (e.g. transparency, integrity, accountability)

- Internal demand (e.g. complex and political goals, many stakeholders)

- Demands originating from the context (e.g. budget-driven, budgets are not fixed)

- Demands on the process (e.g. legislation, difficult to engage in long-term relationships)

- Multiple roles (e.g. large buyers, reciprocity)

The conclusion of Telgen et al.'s article is that public sector procurement is more complex than private sector procurement.

Rendon and Snider (2010) also comprehensively describe why differences exist in terms of the supply management of the business and the public sector. Public procurement has a managerial, legal and political framework; it is part of public budgeting and financial management; there are structural differences between private and public interests; it is less impacted by external influence; and there is a difference between the "bottom line" and "public interest".

Organisational structures, reporting lines and personnel are influenced by the goal structure of organisations. Public procurement is described as having more complex goal-setting processes, but publications that have attempted to grasp the consequences of this provide mixed results. Rainey and Bozeman (2000) highlighted inter alia that public procurement responses do not involve higher goal-setting complexity than in the business sector. Johnson et al. (2003) presented clearer differences in the level of centralisation and supply chain responsibilities, and suggests that more factors should be considered, such as the scope of spending (direct and indirect).

Accordingly, fundamentally different methods and approaches can be detected in several areas of private sector purchasing and public procurement practice. Lian and Laing (2004) studied the buying of healthcare services. Their results show that whereas private sector organisations utilised a range of approaches, public sector organisations almost exclusively relied on 
transaction-based approaches, which was suboptimal. The difference was due to the fact that public procurement was bound by the restrictions imposed by public policy, which - as suggested earlier - is a distinct feature of public procurement (in terms of meeting demands for high levels of accountability and transparency). Roodhooft and Van den Abbeele (2006) generated similar results from a comparison of the buying of consulting services. The authors highlight that public sector organisations may need to develop new purchasing-related skills in areas such as market management, defining specifications, competitive process, and negotiation and monitoring. Burnes and Anastasiadis (2003) prepared case studies that enabled a comparison of the outsourcing of services in both sectors. The authors conclude that neither sector had a monopoly on good practice: the private sector could benefit from the more structured approach of the public sector, and the public sector from the more strategic orientation of the private sector.

The findings of the European and US publications that were reviewed indicate clear and complex reasons for the differences between the purchasing activities of the private and the public sector. This difference has existed for a long period of time, and developments in public administration have only refined the range of factors that strengthen centuries-old differences. The findings of Telgen et al. (2007) and Rendon and Snider (2010) highlight the role of issues which are mainly due to the development of modern society. The mapping of the objectives of public procurement in terms of legal regulations, and the analysis of its possibilities characteristically linked to regulation mean that the purchasing sectors have been handled separately, with the result that although green issues have been awarded priority in both fields, comparisons of the private and public sector are seldom undertaken.

\section{Interpretations of green purchasing and green public procurement}

Sustainability and various 'green' topics are frequently examined in both the public procurement and purchasing literature. As the number of comparative studies is small, the results of investigations into public and non-public procurement are separately described.

\section{Definitions and practices of green purchasing}

One of the early definitions of green purchasing was published by Narasinhan and Carter (1998) who defined environmental supply chain management as "the purchasing function's involvement in activities that include reduction, recycling and reuse and the substitution of materials" (p.6.). This definition focuses on manufacturing companies and on direct material spending. A few years later, Zsidisin and Siferd (2001, p. 69) broadened the definition: "Environmental purchasing for a firm is a subset of purchasing policies held, actions taken and relationships formed in response to concerns associated with the natural environment." This definition highlights the role of internal and external relationships and purchasing tasks and incorporates environmental issues into normal processes and practices in the purchasing function.

As the definitions indicate, green purchasing activities first existed in manufacturing organisations (e.g. Min/Galle, 1997, Carter et al. 1998). Attention soon shifted from direct purchasing transactions to supplier management activities. Related practices described by Arnold et al (1999) go beyond the earlier attempts at manufacturing-oriented impact reduction, recycling and reuse and the substitution of materials to include the role of purchasing in green product design and green supplier management (as reported in a survey of practices). Most green purchasing research still focuses on fundamental issues such as supplier selection; 
recently, however, a number of articles again highlighted more advanced practices such as supplier involvement in green issues, green supplier development, and the dissemination of green practices. Green purchasing research has also revealed that firms need to collaborate with their suppliers to improve performance - monitoring alone is insufficient (Tachizawa et al. 2015). A review of sustainability reports revealed that the application of such practices at most firms were at a relatively early stage (Tate et al. 2012). Recent studies investigate green purchasing in the broader context of green supply chain management (e.g. Zhu et al., 2013). Results indicate that green supply chain management practices can improve economic performance indirectly.

\section{Definitions and practices of green public procurement}

Green Public Procurement (GPP) is defined by the European Commission in the following way: "Public procurement for a better environment" is "a process whereby public authorities seek to procure goods, services and works with a reduced environmental impact throughout their life cycle when compared to goods, services and works with the same primary function that would otherwise be procured." (EC COM 2008)

GPP was highlighted in the Sustainable Action Plan and the Europe 2020 strategy as a key policy tool for developing sustainable growth and creating different environmental, social, economic and political benefits. The European Public Procurement Directives (2014) made green procurement obligatory in EU Member States, greatly facilitating its spread. In EU Member States, contracting authorities are keen to focus on the content of procurement notices that launch such procedures, as well as the evaluation and eligibility criteria therein, as these can be 'greened' more readily through administrative means than technical content or the content of contracts. Arvidsson and Stage (2012) analysed the impact of evaluation criteria expressly from an environmental point of view, drawing attention to the importance of evaluation criteria and their expected positive impact on the environment.

Accordingly, a situation now exists in which environmental criteria in tender evaluations are less widespread and seldom directly affect awarding decisions (Varnäs et al. 2009). In contrast, environmental considerations appear in public procurement primarily at the stage of the development of evaluation and eligibility criteria, rather than in contracts. Referring to this situation, Palmujoki et al. (2010, p. 250) write that "[a]lthough green purchasing criteria are fostered by many EU level and national action plans, and thus are more often included in calls for tenders, it is not necessarily the case that they are integrated into the final contract clauses." Many are dissatisfied with the performance of green procurement because of these administrative solutions (Aspey 2015), while others regard the former expressly as a driver of economic growth (Sikirica 2015) or a means of fostering sustainable production (Testa et al. 2014) or a product of European 'legal thinking' (Staropoli/Steiner 2015). Recent studies of green procurement highlight the innovative nature of the practice; it is no accident that the legal environment constantly refers to green procurement together with sustainable and innovative procurement (Bratt et al. 2013).

\section{Summary of literature review}

Hardly any literature exists that addresses the fundamental question that was defined to guide our research. Thus, when summarising the findings of literature we rely partly on a study by New et al. (2002) and partly on a synthesis of what has been described so far in relation to the individual sectors. 
New et al. (2002) explored interesting similarities in relation to green procurement and purchasing. What is common to both is that the purpose of such activity (supplying an organisation with products and services) is in principle very similar. Other similarities are that the organisational context is very important in both sectors, procurers often find it difficult to relate to the needs of other parts of their organisations, and success is achieved when organisational ties are stronger. As also identified in the literature review, the study highlights one dissimilarity: companies are free to choose their goals and objectives (thus also criteria for evaluating suppliers), while the choice of criteria in the public sector is often subject to intense debate. On the one hand, support for positive goals is to be welcomed, although there is major uncertainty whether the inclusion of environmental criteria in bid evaluation in public procurement, although positive in the short term, has positive effects in the long term.

Our analysis of literature raises the issue of the very different background to the practices of public procurement and corporate sector purchasing. Various studies highlight the variability in legal regulations and the organisational background, adding that there may also be differences in defining the objectives of procurement.

Using the concepts defined above and research into green procurement by companies and public bodies, we have also identified different paths of development with regard to practice. At first, corporate practice took advantage of the opportunity to take environmental criteria into account primarily during the procurement of materials; this practice, however, was later expanded. Also important is that whereas the emphasis was formerly on comparing the content of bids, more recent literature highlights activities related to the management of supplier relations. The change is because a much wider range of instruments and more efficient solutions can be applied to reducing negative environmental impacts through supplier chains. In studies of public procurement it has been acknowledged that the main instrument continues to be the transaction-oriented evaluations of suppliers, while attempts are being made to incorporate more complex impact criteria into the former. In other words, a passive instrument (i.e. green evaluation criteria) is typically used, while procurement practitioners also endeavour to make improvements by using more active instruments (e.g. supplier development).

The absence of literature that expressly addresses this subject matter indicates the existence of an important research gap, and what literature does exist makes it clear that these differences should be identified and studied. For this reason we were able to draw up open statements and logical interrelations in the form of propositions during the course of our research.

Accordingly, the following research framework was developed:

1. Different influences: Proposition one (P1) was that the two groups of actors are differently motivated in relation to their procurement practices and consideration of environmental criteria. A part of this (P1/a) is due to the different motivating influences of the individual groups involved in public procurement and private sector purchasing practice. The literature also indicates differences in the organisational context. Thus our next proposition $(\mathrm{P} 1 / \mathrm{b})$ is that the arrangements of organisational linkages are also different: internal support for environmental issues is much greater in the corporate sector.

2. Different priorities: the impact of internal stakeholders (primarily that of owners and management) appears first and foremost in the set of expectations that are advanced in relation to procurement and purchasing activities. The next proposition (P2) is thus that there is a difference between the priorities of the two sectors. Corporate purchasing 
endeavours to create more efficient supply-side solutions (P2/a), while public procurement focuses on compliance with regulation and process administration $(\mathrm{P} 2 / \mathrm{b})$.

3. Different practices: differences in green practices are clarified by the differing weights assigned to individual activities. Research proposition three (P3) is that, as a result of different motivational effects and different sets of expectations, the appearance of environmental criteria is variable in procurement activities. Public procurement uses a narrower set of instruments and is selection-oriented (P3/a), while private sector purchasing methods include practices that actively influence suppliers in ways that extend beyond evaluation $(\mathrm{P} 3 / \mathrm{b})$.

\section{Research methods}

To validate the research framework, the findings of a survey were used. The survey instrument was based on earlier questionnaires (Arnold et al. 1999, Hasan et al. 2013, Zhu et al. 2005, Zhu et al. 2013) and was distributed to managers of 500 companies based in Hungary. As the response rate was initially low, in a second round the same companies were contacted by telephone. As the response rate was still low $(\mathrm{N}=83$; response rate $16 \%)$, members of a professional association were contacted. The number of responses from public procurement organisations remained low $(\mathrm{N}=20)$ so the questionnaire was then distributed to a list of public procurement organisations.

A total of 135 responses were collected. Respondents were primarily purchasing and supply leaders, purchasing/procurement managers, and in the case of smaller companies, other managers responsible for purchasing.

The sample was split into two groups. The purchasing group (89 responses) contained the responses of companies not subject to European Public Procurement Directives. Several industries were represented here, including manufacturing and service industries. Such companies were mostly large or medium-sized, having over 20 employees, or income greater than approximately 1.7 million euros. The other group consisted of public procurement contracting authorities (46 responses), including private and state-owned companies, universities, hospitals and a municipality.

\section{Survey results}

To test the conceptual framework, the survey results were analysed; the answers of the two groups are now described. All questions were evaluated using a 1-5 scale and responses were compared using Anova.

\section{a/ Different influences}

Differences in stakeholder expectations were frequently mentioned in the literature. Table 1 illustrates how the purchasing and the public procurement group evaluated the influence of some stakeholder-related factors- (The respondents were asked to indicate the level of influence the listed factors have on environmental priorities in a purchasing process. Responses were given using a $1-5$ scale, where $1=$ no influence, $5=$ strong influence).

Table 1

Environmental regulations play an important role in the case of both groups. However, according to the $\mathrm{F}$ value of the Anova analysis, this factor is somewhat more important for the 
purchasing group. The explanation may be that the operations (e.g. manufacturing) of the purchasing group must meet stricter standards. Another influential factor is the cost-saving targets defined by management or owners. This factor was not evaluated significantly differently in the case of the two groups, similarly to top management support, but was perceived to be important by both groups. However, the influence of owners/parent companies' expectations differed: it was evaluated more highly by the purchasing group.

Table 1 indicates that there are differences in the perceived influence of market stakeholders. There was a difference in the case of suppliers, whose availability was deemed more important for the public procurement group. As market position is not perceived significantly differently, the explanation may be related to suppliers' commitment to the environment. The results of the survey indicate that supplier commitment was evaluated as more important by the purchasing group (on the 1-5 scale, the average was 3.101), while the public procurement group evaluated it at 2.761. (F value of 3.104, significant at 0.08 )

The influence of customer/market demand was perceived to be more important by the purchasing group.

The influence of competitors' activity was also perceived to be more important by the purchasing group.

Local communities have a low level of influence on both groups.

\section{b/ Different priorities}

The priorities of the purchasing organisation are influenced by the expectations of management; these also define the focus of purchasing tasks. Table 2 illustrates the respondents' evaluations of the effect of the listed priorities on the efficiency of purchasing. (Responses were given using a 1-5 scale, where 1 = unimportant, 5 = important).

\section{Table 2}

Cost reductions, quality improvement and a better understanding of the supply market were awarded high priority in the case of both groups. As indicated by the F value, there were many differences in the other factors as well.

For the purchasing group it was more important to have long-term partnerships, to decrease the number of suppliers, to qualify suppliers, to improve the performance of existing suppliers, and to manage existing supplier relationships.

For those involved in public procurement it was more important to have more professional education, to improve electronic procurement techniques, and to develop internal coordination systems.

This suggests that the purchasing group identifies supplier management as a means of efficient purchasing, while the public procurement group focuses more on internal management and conformity. The findings can be compared with those presented in Table 1. Supply-side availability was more influential for the public procurement group, while the management of suppliers was more of a priority for the purchasing group. One explanation is that the purchasing group uses more advanced practices, while regulations limit the opportunities of the public procurement group in many ways.

Environment protection was not among the important priorities of either group. This indicates that this factor is not part of formal performance criteria in most cases, although it appears in procurement practices. 


\section{c/ Different practices}

Responses related to the stakeholders indicate the stronger influence of competitors, customers and owner/parent companies on the purchasing group. This is one of the reasons why the company background, in terms of green management, is more important for the purchasing group.

\section{Table 3}

Table 3 indicates the better position of the purchasing group in terms of many features of organisational background. Support from top and middle management is stronger, and these firms are more likely to have ISO 14001 certification and environmental compliance and auditing programs. This supports greater involvement in green purchasing activities.

As indicated in the literature review, the first publications about green purchasing addressed green purchasing activities largely in relation to manufacturing companies. To investigate the differences between green purchasing and green public procurement practices, supplier management-related activities were analysed. Table 4 presents the results of responses about the relevance of the listed items to respondents' current practices. (Responses were given using a 1-5 scale, where $1=$ not applied, 5 = applied)

\section{Table 4}

Purchasing managers indicated greater activity in the case of almost all supplier-related activities. The only exception concerns the requirement that suppliers should have ISO 14001, which criterion is allowed under EU law in public procurement. Analysis with Anova supports this difference. Results are in line with those of Roodhoft and Van den Abbeele (2006).

However, there were no significant differences in terms of the ideal application of supplier management practices. The ideal application of supplier management activities was slightly (but not statistically significantly) higher for the public procurement group. Table 5 illustrates the results, indicating the ideal application and the gap between the current and ideal application for the two groups.

Table 5

Comparison of the ideal and current applications of activities shows that the public procurement group tended to have a larger gap. This indicates that the purchasing group has already developed its practices and are more realistic about the potential applicability of related tools. The biggest gap was identified with using product lifecycle analysis, and the smallest in terms of requiring ISO 14001. The reason may be that life cycle costing has become more prominent in sets of evaluation criteria, as enabled by the European Public Procurement Directives (2014), while requiring ISO compliance has been permitted since 2004. Articles concerning the limits of the application of life cycle analysis have called attention to the peculiarities of its interpretation in public procurement (Tarantini et al. 2011).

\section{Conclusions and agenda for future research}


In summary, we establish that the data obtained from the survey substantiate the propositions contained in all three areas of the research framework.

Different influences: differences were identified in the background of the practices of the two groups (P1). In terms of the differences in motivation, the impact of legal regulations and management support are large. Market impact is weaker for both actors. For purchasers, the influence of customers and competitors are greater than in the case of public procurers, whom the supply side more strongly influences. The organisational context is more supportive of firms' purchasing agents, which New et al. (2002) unambiguously claims improves their potential for development.

Different priorities: the proposition ( $\mathrm{P} 2)$ defined in the research framework appears to be confirmed in this regard. Differences were identified in the factors that determine the efficiency of the procurement system (P2). Although the need to reduce costs is considered important by both groups, private sector purchasers tend to see the solution in supplier management, while public procurement attaches more importance to internal processes. Public procurement agents also attach greater importance to the role of training and education, presumably on account of a constantly changing regulatory framework.

Different practices: we also identified differences with regard to green practices (P3). In addition to the fact that one part of the proposition (P3/a) - namely, that public procurement is selection oriented - was confirmed, the deep impact of regulation was perceptible in the practices that respondents claimed to be engaged in. Purchasing practices also confirmed our propositions; that is, besides the use of simpler instruments (such as supplier evaluation criteria, exclusion of materials harmful to the environment) supplier management activities are more obviously present in the private sector than in the public procurement group.

Our research focused on building a framework for studying the green practices of the private corporate and the public procurement sectors based on the findings of international literature. The results of our survey confirm the differences foreseen during the construction of the framework. An important novelty of our research is that it highlights the different directions of development in private sector and public procurement practices: both literature and our data reflect a shift in the emphasis of private sector purchasing towards supplier management, in contrast to the public sector's transaction-oriented approach. It is also an important finding that respondents from both groups identified best practice concerning supplier management. This conclusion confirms the supposition that the reason for the differences in practice are primarily found in the regulatory environment.

This latter claim is particularly thought provoking, because regulations, and particularly the new EU Public Procurement Directives (2014), were designed with the express intent of encouraging the more intensive consideration of environmental factors. It is thus an important function of the legislation to orient suppliers and the economy towards more environmentally more favourable approaches to spending. The findings presented herein, however, raise important questions in relation to the effects of such measures. In the course of supplier selection, the inclusion of environmental criteria has the economic consequence of increasing demand for environmentally friendly products and reducing demand for other products with the same primary function. It is thus important to examine the related market effects. One possibility is that such measures are stimulating a wave of 'greener' development. Another possibility is that, in accordance with the rules of demand and supply, purchases of green products and services increase overall costs and thus generate demand for cheaper (typically 
less environmentally friendly) products. In such a case, there may be no overall environmental benefit.

In principle, the instruments used in the corporate sector are more environmentally effective: they impact not the volume of demand, but the nature of supply, directly resulting in better environmental performance in terms not only of product characteristics, but also processes.

These conclusions indicate that research into the actual impact of procurement practices on suppliers could constitute an important future research direction.

\section{References}

Arnold, U., Cox, A., Debruyne, M., de Rijcke, J., Heindrick T., Iyogun, P, Liouville, J and Vörösmarty, G. (1999) A multi-country study of strategic topics in purchasing and supply management, Center for Advanced Purchasing Studies Research Report, Tempe, AZ Arvidsson, A and Stage, J. (2012) 'Technology-neutral green procurement in practice-an example from Swedish waste management', Waste Management \& Research, Vol. 30 No. 5, pp.519-523.

Aspey, E. (2015) 'Green technical specifications under the new procurement directives', in Piga, G, Tatrai, T. (eds.). (2015). Public Procurement Policy. Routledge, 205-209.

Basheka, B. (2013) 'The science of public procurement management and administration', in Albano, G. L, Sneider K.F and Thai KV Charting a course in public procurement and knowledge sharing Pr Academic Press Florida, USA Chapter 11, pp.289-330.

Bratt, C, Hallstedt, S, Robèrt, K. H, Broman, G and Oldmark, J. (2013) 'Assessment of criteria development for public procurement from a strategic sustainability perspective', Journal of Cleaner Production, Vol. 52, pp.309-316.

Burnes, B and Anastasiadis, A. (2003)'Outsourcing: a public-private sector comparison', Supply Chain Management: An International Journal, Vol. 8 No. 4, pp.355 - 366.

Carter, C.R., Ellram, L.M. and Ready, K.J. (1998) 'Environmental purchasing: Benchmarking Our German Counterparts', International Journal of Purchasing and Materials Management, Vol.34 No.4, pp.28-37.

Dubey, R., Bag, S., Ali, S. S., \& Venkatesh, V. G. (2013). Green purchasing is key to superior performance: an empirical study. International Journal of Procurement Management, Vol. 6 No. 2, pp. 187-210.

EC COM (2008) Communication from the Commission to the European Parliament, the Council, the European Economic and Social Committee and the Committee of the Regions Public procurement for a better environment $\{$ SEC(2008) 2124\} $\{$ SEC(2008) 2125\} 
$\{\operatorname{SEC}(2008) \quad 2126\} \quad / * \quad \operatorname{COM} / 2008 / 0400 \quad$ final $* / \quad$ http://eur-lex.europa.eu/legalcontent/EN/TXT/HTML/?uri=CELEX:52008DC0400\&from=EN

Europe 2020 (2010) A Strategy for Smart, Sustainable and Inclusive Growth. European Commission. Brussels.

European Public Procurement Directives (2014) Directive 2014/24/EU of the European Parliament and of the Council of 26 February 2014 on public procurement and repealing Directive 2004/18/EC; Directive 2014/25/EU of the European Parliament and of the Council of 26 February 2014 on procurement by entities operating in the water, energy, transport and postal services sectors and repealing Directive 2004/17/EC; Directive 2014/23/EU of the European Parliament and of the Council of 26 February 2014 on the award of concession contracts Grubic-Nesic, L., Mitrovic, S., Melovic, B. and Milisavljevic, S. (2016) 'Differences between the state/public and private sectors in organizations in Serbia regarding the functionality of managers' decision making', Journal for East European Management Studies, Vol.21 No.1, pp.1-21.

Hasan, M. (2013) 'Sustainable Supply Chain Management Practices and Operational Performance', American Journal of Industrial and Business Management, Vol.3 No.1, pp.4248.

Leenders, M. and Fearon, H. E. (2008) 'Developing Purchasing's Foundation', Journal of Supply Chain Management, Vol. 44. No. 2, pp.17-27.

Lian, P.C.S and Laing, A. W. (2004) 'Public sector purchasing of health services: a comparison with private sector purchasing', Journal of Purchasing and Supply Management, Vol.10 No.6, pp.247-256.

Min, H and Galle, W.P. (1997) 'Green Purchasing Strategies: Trends and Implications', International Journal of Purchasing and Materials Management, Vol.33 No.2, pp.10-17.

Malovics, G, Racz, G. and Kraus, S. (2007) 'The role of environmental management systems in hungary - theoretical and empirical insights', Journal for East European Management Studies, 12 3., 180-204. Retrieved from http://search.proquest.com/docview/232777461? accountid=15545

Narasimhan, R and Carter, J. (1998) Environmental Supply Chain Management, Center for Advanced Purchasing Studies, Tempe, AZ

New, S, Green, K and Morton B, (2002) 'An analysis of private versus public sector responses to environmental challenges of the supply chain', Journal of Public Procurement, Vol.2 No.1, pp.93-105 
Palmujoki, A, Parikka-Alhola, K and Ekroos, A. (2010) 'Green public procurement: analysis on the use of environmental criteria in contracts', Review of European Community and International Environmental Law, Vol.19 No.2, pp.250-262.

Rainey, H. G and Bozeman, B. (2000) 'Comparing public and private organisations: empirical research and the power of a priori', Journal of Public Administration Research and Theory, Vol.10 No.2, pp.447-469.

Rendon, R. G and Snider, K. F. (2010) 'Supply management in American public administration: Towards an academic discipline', Journal of Purchasing and Supply Management, Vol.16, pp.99-108.

Roodhooft, F and Van der Abbele, A. (2006) 'Public procurement of consulting services, Evidence and comparison with private companies', International Journal of Public Sector Management, Vol.19 No.5, pp.490-512.

Sikirica, V. (2015) 'Procurement for sustainable development'. in Piga, G, Tatrai, T. (eds.). (2015). Public Procurement Policy. Routledge. pp.178-204.

Staropoli, C, and Steiner, M (2015) ‘10 Colloquium’, Public Procurement Policy, pp.163177.

Tachizawa, E.M, Giminez, C and Sierra, V (2015) 'Green supply chain management approaches: drivers and performance implications', International Journal of Operations and Production Management, Vol.35 No.11, pp.1546-1566.

Tarantini, M, Loprieno A. D and Porta, P L (2011) 'A life cycle approach to Green Public Procurement of building materials and elements: A case study on windows', Energy, Vol.36 No.5, pp.2473-2482.

Tate, W, Ellram, L.M and Dooley, K. (2012) 'Environmental purchasing and supplier management (EPSM): Theory and practice', Journal of Purchasing and Supply Management Vol.18, pp.173-188.

Telgen, J, Harland, C and Knight, L (2007) 'Public procurement in perspective'. in L Knight, C Harland, J Telgen, KV Thai, G Callender and K McKen (eds), Public procurement: international cases and commentary. Routledge, Abingdon (UK), pp.16-24.

Testa, F, Annunziata, E, Iraldo, F and Frey, M (2014) Drawbacks and opportunities of green public procurement: an effective tool for sustainable production. Journal of Cleaner Production, Vol.112, pp.1893-1900.

Varnäs, A, Balfors, B and Faith-Ell, C (2009) 'Environmental consideration in procurement of construction contracts: current practice, problems and opportunities in green procurement in the Swedish construction industry', Journal of Cleaner Production, Vol.17 No.13, pp.1214-1222. 
Vatalis, K. I, Manoliadis, O. G and Mavridis, D G (2012) 'Project performance indicators as an innovative tool for identifying sustainability perspectives in green public procurement', Procedia Economics and Finance, Vol. 1, pp.401-410.

Walker, H, Di Sisto, L and McBain, D. (2008) 'Drivers and barriers to environmental supply chain management practices: Lessons from the public and private sectors', Journal of Purchasing and Supply Management, Vol. 14, pp.69-85., doi:10.1016/j.pursup.2008.01.007

Zhu, Q, Sarkis, J and Geng, Y. (2005) 'Green supply chain management in China: pressures, practices and performance', International Journal of Operations and Production Management, Vol. 25 No.5, pp. 449-468

Zhu, Q, Sarkis, J and Lai, K (2013) 'Institutional-based antecedents and performance outcomes of internal and external green supply chain management practices', Journal of Purchasing and Supply Management, Vol.19 No.2, pp. 106-117.

Zsidisin, G. A. and Siferd, S.. P. (2001) 'Environmental purchasing: a framework for theory development', European Journal of Purchasing \& Supply Management, Vol.7 No.1, pp. 61-73 
Table 1 Influence of stakeholder related factors

\begin{tabular}{|l|c|c|c|c|}
\hline & Purchasing & $\begin{array}{c}\text { Public } \\
\text { procurement }\end{array}$ & Difference & $\mathrm{F}$ \\
\hline Number of suppliers & 3.146 & 3.511 & -0.365 & $3.913^{* *}$ \\
\hline Market position of purchasing & 3.303 & 3.467 & -0.163 & 0.751 \\
\hline Environmental regulations & 4.270 & 3.956 & 0.314 & $2.792^{*}$ \\
\hline Customer/market demand & 4.056 & 3.578 & 0.478 & $6.284^{* *}$ \\
\hline Competitors activity & 3.247 & 2.778 & 0.469 & $4.428^{* *}$ \\
\hline Motivation of the owners/parent comp & 3.764 & 3.295 & 0.469 & $4.252^{* *}$ \\
\hline Top management support & 3.955 & 3.800 & 0.155 & 0.582 \\
\hline Cost saving targets & 4.000 & 4.089 & -0.089 & 0.217 \\
\hline Environmental targets & 3.685 & 3.756 & -0.070 & 0.137 \\
\hline Expectation of local communities & 3.193 & 3.022 & 0.171 & 0.709 \\
\hline
\end{tabular}

*significant at $<10 \%, * *$ significant at $<5 \%$

Table 2 Aspects of efficiency in purchasing

\begin{tabular}{|l|c|c|c|c|}
\hline & Purchasing & $\begin{array}{c}\text { Public } \\
\text { procurement }\end{array}$ & Difference & F \\
\hline Cost reduction & 4.517 & 4.348 & 0.169 & 1.330 \\
\hline Quality improvements & 4.079 & 4.043 & 0.035 & 0.045 \\
\hline Long term partnership with suppliers & 4.101 & 3.717 & 0.384 & $5.529^{* *}$ \\
\hline Decreasing the number of suppliers & 3.124 & 2.565 & 0.558 & $8.922^{* *}$ \\
\hline Qualifying suppliers & 3.764 & 3.326 & 0.438 & $4.892^{* *}$ \\
\hline $\begin{array}{l}\text { Improve the performance of existing } \\
\text { suppliers }\end{array}$ & 3.764 & 3.457 & 0.308 & $0.247^{*}$ \\
\hline Professional education & 3.382 & 3.739 & -0.357 & $2.993^{*}$ \\
\hline $\begin{array}{l}\text { Improve electronic procurement } \\
\text { techniques }\end{array}$ & 3.483 & 4.065 & -0.582 & $8.815^{* *}$ \\
\hline Developing internal coordination & 3.730 & 4.065 & -0.335 & $3.418^{*}$ \\
\hline Better understanding of supply markets & 4.057 & 4.087 & -0.030 & 0.028 \\
\hline $\begin{array}{l}\text { Increased use of electronic solutions in } \\
\text { purchasing }\end{array}$ & 3.573 & 3.674 & -0.101 & 0.274 \\
\hline $\begin{array}{l}\text { Managing relationship with existing } \\
\text { suppliers }\end{array}$ & 3.865 & 3.543 & 0.322 & $3.605^{*}$ \\
\hline $\begin{array}{l}\text { Improve the methodology used in } \\
\text { procurement }\end{array}$ & 3.607 & 3.652 & -0.045 & 0.052 \\
\hline Environment protection & 3.371 & 3.239 & 0.132 & 0.372 \\
\hline
\end{tabular}

$*$ significant at $<10 \%, * *$ significant at $<5 \%$ 
Table 3 Organisational background of green purchasing and green public procurement

\begin{tabular}{|l|c|c|c|c|}
\hline & Purchasing & $\begin{array}{c}\text { Public } \\
\text { procurement }\end{array}$ & Difference & F \\
\hline $\begin{array}{l}\text { Top management supports environmental } \\
\text { developments }\end{array}$ & 3.798 & 3.370 & 0.428 & $5.028^{* *}$ \\
\hline $\begin{array}{l}\text { Top management supports environmental } \\
\text { developments mostly if they deliver } \\
\text { savings }\end{array}$ & 4.011 & 3.696 & 0.316 & $3.17^{*}$ \\
\hline $\begin{array}{l}\text { There are environmental goals among the } \\
\text { priorities of purchasing }\end{array}$ & 3.247 & 3.000 & 0.247 & 1.462 \\
\hline $\begin{array}{l}\text { Superiors of purchasing support green } \\
\text { solutions }\end{array}$ & 3.730 & 3.370 & 0.361 & $3.691^{* *}$ \\
\hline $\begin{array}{l}\text { Our company has an environmental } \\
\text { management system }\end{array}$ & 3.090 & 2.674 & 0.416 & 1.986 \\
\hline Our company has ISO14001 certification & 2.944 & 2.267 & 0.677 & $4.231^{* *}$ \\
\hline $\begin{array}{l}\text { Our company has environmental } \\
\text { compliance and auditing program }\end{array}$ & 2.955 & 2.283 & 0.672 & $4.65^{* *}$ \\
\hline $\begin{array}{l}\text { Purchasing and supply employees get } \\
\text { environmental training }\end{array}$ & 2.125 & 1.848 & 0.277 & 1.669 \\
\hline
\end{tabular}

*significant at $<10 \%$, ** significant at $<5 \%$

Table 4 Differences in green supply management

\begin{tabular}{|l|c|c|c|c|}
\hline & Purchasing & $\begin{array}{c}\text { Public } \\
\text { procurement }\end{array}$ & Difference & $\mathrm{F}$ \\
\hline $\begin{array}{l}\text { Supplier evaluation includes environmental } \\
\text { requirements for purchased items }\end{array}$ & 2.854 & 2.435 & 0.419 & $3.023^{*}$ \\
\hline $\begin{array}{l}\text { Supplier evaluation includes environmental } \\
\text { requirements for the suppliers operations }\end{array}$ & 2.640 & 2.217 & 0.423 & $3.134^{*}$ \\
\hline $\begin{array}{l}\text { Supplier evaluation includes environmental } \\
\text { requirements for packaging }\end{array}$ & 2.831 & 2.130 & 0.701 & $9.022^{* *}$ \\
\hline $\begin{array}{l}\text { Product lifecycle analysis is part of supplier } \\
\text { evaluation }\end{array}$ & 2.584 & 2.000 & 0.584 & $7.261^{* *}$ \\
\hline $\begin{array}{l}\text { Product content restrictions (Product must } \\
\text { not contain environmentally undesirable } \\
\text { attributes) }\end{array}$ & & & & \\
\hline $\begin{array}{l}\text { Disclosure of the environmental attributes of } \\
\text { product content by the supplier is required }\end{array}$ & 2.730 & 2.283 & 0.448 & $3.275^{*}$ \\
\hline Supplier is required to have ISO 14001 & 2.517 & 2.891 & -0.374 & 2.137 \\
\hline $\begin{array}{l}\text { Ask suppliers to commit to waste reduction } \\
\text { goals }\end{array}$ & 2.562 & 2.043 & 0.518 & $5.423^{* *}$ \\
\hline $\begin{array}{l}\text { Environmental assessment of suppliers' } \\
\text { processes }\end{array}$ & 2.461 & 1.935 & 0.526 & $7.019^{* *}$ \\
\hline $\begin{array}{l}\text { Cooperation with the suppliers to develop } \\
\text { environmentally better products }\end{array}$ & 2.258 & 1.739 & 0.519 & $6.401^{* *}$ \\
\hline Educate suppliers about environmental issues & 1.978 & 1.543 & 0.434 & $5.613^{* *}$ \\
\hline
\end{tabular}


*significant at $<10 \%, * *$ significant at $<5 \%$

Table 5 Differences of the current and ideal supply management

\begin{tabular}{|c|c|c|c|c|}
\hline & $\begin{array}{c}\text { Purchasing } \\
\text { ideally }\end{array}$ & $\begin{array}{l}\text { Public } \\
\text { proc. } \\
\text { ideally }\end{array}$ & $\begin{array}{l}\text { Purchasing } \\
\text { gap }\end{array}$ & $\begin{array}{l}\text { Public } \\
\text { proc. gap }\end{array}$ \\
\hline $\begin{array}{l}\text { Supplier evaluation includes environmental } \\
\text { requirements for purchased items }\end{array}$ & 3.697 & 3.957 & 0.843 & 1.522 \\
\hline $\begin{array}{l}\text { Supplier evaluation includes environmental } \\
\text { requirements for the suppliers operations }\end{array}$ & 3.618 & 3.804 & 0.978 & 1.587 \\
\hline $\begin{array}{l}\text { Supplier evaluation includes environmental } \\
\text { requirements for packaging }\end{array}$ & 3.697 & 3.717 & 0.865 & 1.587 \\
\hline $\begin{array}{l}\text { Product lifecycle analysis is part of supplier } \\
\text { evaluation }\end{array}$ & 3.517 & 3.848 & 0.933 & 1.848 \\
\hline $\begin{array}{l}\text { Product content restrictions (Product must } \\
\text { not contain environmentally undesirable } \\
\text { attributes) }\end{array}$ & 3.944 & 4.022 & 0.663 & 1.522 \\
\hline $\begin{array}{l}\text { Disclosure of the environmental attributes } \\
\text { of product content by the supplier is } \\
\text { required }\end{array}$ & 3.438 & 3.696 & 0.708 & 1.413 \\
\hline Supplier is required to have ISO 14001 & 3.360 & 3.957 & 0.843 & 1.065 \\
\hline $\begin{array}{l}\text { Ask suppliers to commit to waste reduction } \\
\text { goals }\end{array}$ & 3.483 & 3.500 & 0.921 & 1.457 \\
\hline $\begin{array}{l}\text { Environmental assessment of suppliers' } \\
\text { processes }\end{array}$ & 3.393 & 3.500 & 0.933 & 1.565 \\
\hline $\begin{array}{l}\text { Cooperation with the suppliers to develop } \\
\text { environmentally better products }\end{array}$ & 3.213 & 3.388 & 0.955 & 1.649 \\
\hline $\begin{array}{l}\text { Educate suppliers about environmental } \\
\text { issues }\end{array}$ & 3.056 & 3.109 & 1.079 & 1.565 \\
\hline
\end{tabular}

